\title{
Zagrożenie zabytków dziedzictwa kulturowego ruchami masowymi na obszarze Karpat
}

\author{
Izabela Laskowicz ${ }^{1}$, Teresa Mrozek ${ }^{2}$
}

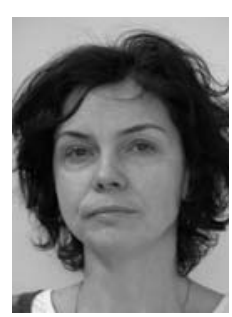

I. Laskowicz

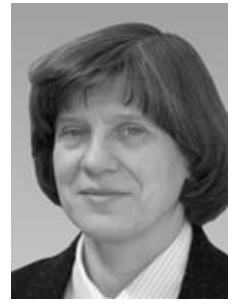

T. Mrozek

Cultural heritage affected by landslides in the Carpathians. Prz. Geol, 67: 369-376; doi: $10.7306 / 2019.31$

A b s t r a c t. Owing to intensification of extreme rainfall events widespread land-sliding has been observed in the Carpathians since the 1990s. This area is also known for many cultural heritage objects e.g. manors, castles, sacred buildings, technical structures, whole villages and urban layouts. Here, the natural propensity to slope failure was often overlooked, so was a potential landslide hazard. This work presents the list of cultural heritage objects that have been affected by a landslide hazard. and that total to 445 historic sites. In the group of the most endangered, there are 12 heritage buildings located on active landslides. Using selected examples of masonry and wooden structures, the sacred historical heritage assets and manors are discussed in a context of landsliding threats and related preventive measures. This paper also shows that the structural stabilization implemented for a historical site was successful and withstood an impact of extreme precipitation during the spring/summer 2010. However, the assessment of landslide hazard requires, first of all, a full inventory of the threatened monuments and historical sites.

Keywords: landslides hazard, heritage, monuments, stabilization, monitoring.

Intensyfikacja procesów osuwiskowych obserwowana w ostatnim ćwierćwieczu (głównie w latach: 1997, 2001, 2002 oraz 2010 r.) potwierdza, że szczególnie południowa część Polski w zasięgu Karpat i ich przedgórza jest realnie narażona na poważne szkody wywołane ruchami masowymi. Oszacowany rozmiar strat kwalifikuje ruchy masowe z lat 1997 i 2010 r. do co najmniej średnich lub nawet bardzo poważnych katastrof naturalnych (Poprawa i in., 1998; Munich Re, 2006; Wirtz, 2008; Grabowski, Przybycin, 2010; Laskowicz, Mrozek, 2018). Wielkość strat w odniesieniu do obiektów budowlanych lub użytków rolnych można ocenić, obliczając ich wartość odtworzeniową, czyli koszty potrzebne do restytucji stanu sprzed zniszczenia (Giacoemelli, 2003).

Inaczej jest w przypadku zabytków dziedzictwa kulturowego. O wielkości strat nie świadczą wyłącznie nakłady finansowe potrzebne do odtworzenia stanu i funkcji obiektu po katastrofie. Zniszczony zabytek, nawet zrekonstruowany, pozostaje już tylko replika, a nie obiektem historycznym (Bukal, 2013). Określanie wartości zabytków, pomimo braku czytelnych i oficjalnych kryteriów oceny, jest realizowane przede wszystkim na potrzeby prac konserwatorskich. Odbywa się ono na podstawie subiektywnie określanych aspektów, m.in. takich jak wartość historyczna, artystyczna lub naukowe znaczenie obiektu. Jedynym mierzalnym wskaźnikiem może być tylko wiek zabytku, a ściślej jego zabytkowej substancji, czyli tego, co fizycznie zachowało się w nim z przeszłości. Materialny budulec obiektu, to także jedyny aspekt zabytku, który nie może być odtworzony w przypadku zniszczenia. Pozostałe, takie jak forma czy kontekst przestrzenny, szczególnie przy obecnych możliwościach technologicznych, są stosunkowo łatwe do zastapienia repliką, tak jak w odbudowanym w całości Zamku Królewskim w Warszawie lub częściowej rekonstrukcji na zamku w Rabsztynie. Nawet tak ulotny wydawałoby się aspekt jak wartość emocjonalna zabytku, pomimo zniszczenia substancji, pozostaje żywy w pamięci ludzkiej. Zatem sednem zachowania (a nie odtworzenia) obiektu zabytkowego jest utrzymanie i konserwacja jego „budulca”, jako materialnej substancji (Bukal, 2013).

Zagrożenia dla zabytkowych obiektów generalnie dzieli się na dwie grupy (Canuti i in., 2009):

- naturalne, np. powodzie, huragany, wegetacja, mikroorganizmy, trzęsienia ziemi,

- oraz antropogeniczne, np. realizacje inwestycji o znaczeniu strategicznym, ale także wandalizm czy działania wojenne.

Wśród zagrożeń szczególną rolę odgrywają powierzchniowe ruchy masowe, które $\mathrm{z}$ jednej strony są warunkowane czynnikami naturalnymi takimi jak: budowa geologiczna, geometria stoku, nawodnienie wodami opadowymi i roztopowymi, zmiany ciśnienia w porach gruntu itp. $Z$ drugiej strony mogą to być także aktywowane przez czynniki antropogeniczne, takie jak np. prace budowlane, wylesienie, niewłaściwa gospodarka wodno-ściekowa itp. Tym zagrożeniom przeciwdziała się między innymi przez modyfikacje nachylenia stoku, ograniczenie infiltracji wody, wprowadzanie umocnień biotechnicznych, stabilizacje strukturalne itp.

Współcześnie w polskich Karpatach powierzchniowe ruchy masowe stanowią jeden $\mathrm{z}$ istotniejszych czynników wpływających destrukcyjnie na obiekty zabytkowe. W niniejszej pracy przedstawiono skalę tego zagrożenia w Karpatach oraz na wybranych przykładach pokazano jak groźne dla zabytków mogą być ruchy masowe, a także jakie działania są podejmowane w celu ochrony dziedzictwa kulturowego przed ich skutkami.

\footnotetext{
${ }^{1}$ Państwowy Instytut Geologiczny - Państwowy Instytut Badawczy, Centrum Geozagrożeń, ul. Skrzatów 1, 31-560 Kraków; izabela.laskowicz@pgi.gov.pl

${ }^{2}$ Emerytowny pracownik Państwowego Instytutu Geologicznego - Państwowego Instytutu Badawczego; terkmro@gmail.com
} 


\section{METODYKA}

Dla oceny zagrożenia osuwiskowego obiektów zabytkowych konieczna jest przede wszystkim inwentaryzacja zarówno przejawów ruchów masowych, jak i stanu technicznego obiektów zabytkowych, z uwzględnieniem przestrzennej oceny zagrożeń. Wyniki tych prac stanowią bazę do dalszych działań, w szczególności do zindywidualizowanej analizy ryzyka osuwiskowego. Niniejszy przegląd i ocena obejmuje zabytki nieruchome, które ustawa o ochronie zabytków i opiece nad zabytkami z dn. 23 lipca 2003 r. (Ustawa, 2003) określa jako ...nieruchomość, jej część lub zespót nieruchomości (...) będqce dziełem człowieka lub zwiazane z jego działalnościa $i$ stanowiace świadectwo minionej epoki badź zdarzenia, których zachowanie leży w interesie społecznym ze względu na posiadana wartość historyczna, artystyczna lub naukowa. Posługując się rejestrem obiektów zabytkowych znajdującym się w zasobach Narodowego Instytutu Dziedzictwa (NID), wykonano przestrzenną analizę zagrożenia osuwiskowego obiektów zabytkowych na obszarze Karpat, polegającą na zestawieniu map osuwisk i lokalizacji obiektów zabytkowych (www.nid.pl). Wykorzystano mapy osuwisk wykonanych w skali 1:10 000 w latach 2008-2018 (osuwiska.pgi.gov.pl). Na mapach są zaznaczone granice osuwisk z podziałem na trzy stopnie aktywności: osuwiska aktywne w ostatnich pięciu latach przed rejestracją, okresowo aktywne, których aktywność miała miejsce w okresie 5-50 lat przed rejestracja, oraz nieaktywne od 50 lat (Grabowski $\mathrm{i}$ in., 2008). Za obszar szczególnie zagrożony ruchami masowymi należy uznać także tereny przylegające do form osuwiskowych ze względu na możliwość ich rozwoju i powiększania zasięgu. Problematyka tempa rozwoju osuwisk jest zagadnieniem złożonym, ponieważ poszczególne strefy osuwisk rozwijają się ze zróżnicowanym natężeniem i w odmiennym czasie (Záruba, Mencl, 1982). Posiłkując się wynikami badań szczegółowych obserwacji prowadzonych $\mathrm{m}$.in. w połowie XX w. przez Gerlacha (1966), a także przez innych autorów (Raczkowski, 2007; Chowaniec, Wójcik, 2012; Graniczny i in., 2012), przyjęto bufor wokół osuwisk o szerokości $30 \mathrm{~m}$ od granic osuwisk, który uznano za obszar szczególnie zagrożony dalszym rozwojem przemieszczeń. Kryterium takie jest jedynie wielkością szacunkową, nie potwierdzoną wystarczającą liczbą obserwacji.

Zabytki do celów omawianej analizy zostały pogrupowane (z uwzględnieniem klasyfikacji NID). Wyróżniono obiekty o rozmiarach typowych dla budynku, budowli czy też tzw. małej architektury, które wraz ze zmniejszeniem skal odwzorowania kartograficznego traktuje się jako punktowe. Drugim typem są obiekty o charakterze obszarowym, których granice można wskazać na planach i mapach wielkoskalowych (np. założenia urbanistyczne, parki). W ich skład mogą wchodzić także obiekty budowlane, stanowiąc łącznie zespół objęty ochroną.

W związku z takim kryterium grupowania zastosowany podział przedstawia się następująco:

a) obiekty o charakterze punktowym:

- budynki mieszkalne, w tym wille, pensjonaty, kamienice, chałupy wiejskie,

- dwory, w tym też zespoły dworskie, zespoły pałacowe,

- obiekty sakralne - kościoły, cerkwie, kaplice, synagogi, kapliczki, dzwonnice, kalwarie, budynki klasztorne,
- zamki,

- obiekty techniczne i gospodarskie - fabryki, urządzenia hydrotechniczne, stajnie, spichlerze, obory, budynki gospodarcze, bramy, forty, szkoły,

b) obiekty o charakterze obszarowym:

- zespoły urbanistyczne i ruralistyczne - miasta, wsie, założenia urbanistyczne,

- parki i zieleń - aleje, parki, oranżerie, otoczenia zielone, tereny przykościelne, parki dworskie,

- cmentarze, m.in. wojenne z I i II wojny światowej, komunalne, przykościelne, o różnym charakterze kulturowo-wyznaniowym, np. rzymskokatolickie, żydowskie,

- inne obszary objęte ochroną konserwatorską.

Każdy nieruchomy zabytek, który znajduje się równocześnie w dwóch lub więcej wydzielonych strefach zagrożenia osuwiskowego (osuwiska aktywne, okresowo aktywne, nieaktywne, strefa buforowa), był kwalifikowany do strefy o wyższym zagrożeniu. Na przykład jeżeli założenie urbanistyczne znajduje się zarówno w granicach osuwisk nieaktywnych, jak i w ich strefie buforowej zostało w całości zaliczone do strefy osuwisk nieaktywnych.

Celem prezentowanej analizy jest wstępne przybliżenie zagadnienia zagrożenia zabytków przez ruchy masowe i próba określenia jego wielkości tego na obszarze Karpat. Należy jednak podkreślić, że inwentaryzacja osuwisk prowadzona w ramach projektu Systemu Osłony Przeciwosuwiskowej (SOPO) w skali 1: 10000 nie została jeszcze ukończona (osuwiska.pgi.gov.pl). Na koniec 2018 r. 82\% powierzchni Karpat posiadało szczegółowe rozpoznanie przejawów ruchów masowych. $Z$ tego powodu analiza dotyczy tej części, w której prace zostały obecnie zrealizowane.

\section{ZABYTKI DZIEDZICTWA KULTUROWEGO ZAGROŻONE PRZEZ POWIERZCHNIOWE RUCHY MASOWE W KARPATACH}

Za zabytki zagrożone uznano wszystkie obiekty i obszary znajdujące się w całości lub częściowo w granicach osuwisk oraz we wspomnianej strefie buforowej w odległości do $30 \mathrm{~m}$ od granicy osuwiska (tab. 1).

Na obszarze Karpat na obszarach osuwiskowych można obecnie wskazać 445 chronione prawem obiekty zabytkowe, w tym 207 obiekty budowlane uznane za odrębne obiekty zabytkowe. Za najbardziej zagrożone należy uznać te, które znajdują się w całości lub częściowo w granicach osuwisk aktywnych. Jest to obecnie 12 zabytkowych obiektów budowlanych. Kolejnych 28 obiektów znajduje się w obrębie osuwisk okresowo aktywnych. Chociaż zagrożenie zabytków znajdujących się w granicach osuwisk nieaktywnych od 50 lat można by uznać za mniejsze, to jednak nie należy go całkowicie bagatelizować. Zwykle na takich rozległych i często głęboko uwarunkowanych strukturalnie osuwiskach powtarzalność ruchów masowych następuje po dłuższym czasie nieaktywności. Jak pokazuje przypadek osuwiska w Łaśnicy k. Lanckorony skala zniszczeń wywołanych przez takie powierzchniowe ruchy masowe jest nieporównywalnie większa niż w przypadku mniejszych, częściej uruchamianych osuwisk (Ziętara, 1969; Chowaniec, Wójcik, 2012; Graniczny i in., 2012).

Za potencjalnie zagrożone należy także uznać obiekty znajdujące się poza osuwiskami, w odległości do $30 \mathrm{~m}$ od ich granic. Jest to strefa bardzo prawdopodobnego 
Tab. 1. Zabytki na obszarze Karpat zagrożone ruchami masowymi Table 1. Cultural heritage affected by landslides in the Carpathians

\begin{tabular}{|c|c|c|c|c|}
\hline \multirow{3}{*}{$\begin{array}{c}\text { Grupa zabytków } \\
\text { Group of cultural heritage } \\
\text { objects }\end{array}$} & \multicolumn{4}{|c|}{$\begin{array}{l}\text { Liczba zabytków } \\
\text { Number of cultural heritage objects }\end{array}$} \\
\hline & $\begin{array}{l}\text { osuwiska aktywne } \\
\text { actice landslides }\end{array}$ & $\begin{array}{c}\text { osuwiska okresowo } \\
\text { aktywne } \\
\text { periodically active } \\
\text { landslides }\end{array}$ & $\begin{array}{l}\text { osuwiska nieaktywne } \\
\text { inactive landslides }\end{array}$ & $\begin{array}{l}\text { bufor } 30 \mathrm{~m} \\
\text { 30-m wide buffor zone }\end{array}$ \\
\hline & \multicolumn{4}{|c|}{$\begin{array}{c}\text { obiekty o charakterze punktowym } \\
\text { point-type objects }\end{array}$} \\
\hline $\begin{array}{l}\text { Budynki mieszkalne } \\
\text { Houses }\end{array}$ & - & 5 & 15 & 34 \\
\hline $\begin{array}{l}\text { Dwory } \\
\text { Manors }\end{array}$ & 3 & 7 & 8 & 9 \\
\hline $\begin{array}{l}\text { Obiekty sakralne } \\
\text { Sacred objects }\end{array}$ & 5 & 12 & 23 & 33 \\
\hline $\begin{array}{l}\text { Zamki } \\
\text { Castles }\end{array}$ & 2 & - & 1 & - \\
\hline $\begin{array}{l}\text { Obiekty techniczne } \\
\text { i gospodarskie } \\
\text { Technical objects } \\
\text { and outbuildings }\end{array}$ & 2 & 4 & 14 & 30 \\
\hline \multirow[t]{2}{*}{$\begin{array}{l}\text { Lacznie obiekty } \\
\text { o charakterze punktowym } \\
\text { Total of point-type objects }\end{array}$} & 12 & 28 & 61 & 106 \\
\hline & \multicolumn{4}{|c|}{$\begin{array}{c}\text { obiekty o charakterze obszarowym } \\
\text { area-type objects }\end{array}$} \\
\hline $\begin{array}{l}\text { Cmentarze } \\
\text { Cemeteries }\end{array}$ & 9 & 21 & 4 & 30 \\
\hline $\begin{array}{l}\text { Obszary objęte ochroną } \\
\text { konserwatorska } \\
\text { Objects under legal } \\
\text { conservation }\end{array}$ & 8 & 19 & 1 & 9 \\
\hline $\begin{array}{l}\text { Założenia urbanistyczne } \\
\text { i ruralistyczne } \\
\text { Urban and rural layouts }\end{array}$ & 6 & 5 & 1 & 4 \\
\hline $\begin{array}{l}\text { Parki i zieleń } \\
\text { Parks and greenlands }\end{array}$ & 18 & 29 & 18 & 56 \\
\hline $\begin{array}{l}\text { Łącznie obiekty } \\
\text { o charakterze obszarowym } \\
\text { Total of area-type objects }\end{array}$ & 41 & 74 & 24 & 99 \\
\hline $\begin{array}{l}\text { Lacznie } \\
\text { Total }\end{array}$ & 53 & 102 & 85 & 205 \\
\hline
\end{tabular}

źródło / sources: osuwiska.pgi.gov.p; www.nid.pl

przemieszczania gruntu w przypadku rozwoju istniejącego osuwiska w sąsiedztwie. Do tej strefy zaliczono wyłącznie obiekty, które znajdowały się poza osuwiskami, a jedynie w całości lub w części w strefie buforowej. Łącznie stanowią one $46 \%$ wszystkich zabytków uznanych za zagrożone przez ruchy masowe.

Spośród rozpatrywanych obiektów zabytkowych znajdujących się na obszarze osuwisk lub w ich bliskim sąsiedztwie 46,5\% stanowią różnej funkcji obiekty o charakterze punktowym. Pozostałe to wydzielenia przestrzenne, np. parki i zieleń, cmentarze ale także założenia urbanistyczne objęte ochroną w rozumieniu ustawy o ochronie zabytków i opiece nad zabytkami (Ustawa, 2003). Ryzyko zniszczenia zależy od formy i konstrukcji obiektów poddanych działaniu czynników geodynamicznych z uwzględnieniem ich wielkości i kierunku. W każdym przypadku wspomniane ryzyko jest zindywidualizowane w zależności od warunków geologiczno-inżynierskich i cech konstrukcyjnych obiektów. Dlatego też sporządzenie szczegółowej listy wszystkich analizowanych obiektów wymaga określenia ich charakteru konstrukcyjno-funkcjonalnego oraz kontekstu przestrzennego, tak aby określić indywidualnie zagrożenie i ryzyko osuwiskowe.
Jak wynika z przedstawionej powyżej analizy zarówno zabytki odwzorowywane punktowo, jaki i obiekty zabytkowe o charakterze przestrzennym są narażone na destrukcyjne oddziaływanie ruchów masowych w Karpatach. Spośród zabytków poddanych niszczącemu działaniu osuwiskowemu blisko połowę stanowią obiekty budowlane. Poniżej przedstawiamy wybrane przykłady ilustrujące różny charakter geologicznych uwarunkowań osuwisk oraz działania podejmowane w celu eliminacji bądź redukcji zagrożeń. Rozpatrywany jest charakter i rozmiary zniszczeń obiektów zabytkowych posadowionych na osuwiskach, rozwiniętych w różnych utworach geologicznych (np. warstwy godulskie, krośnieńskie, inocermowe) i aktywowanych przez opady o różnej intensywności. Pod względem strategii prac zabezpieczających podawane tu przykłady pokazują zarówno odstąpienie od rekonstrukcji w wybranej lokalizacji (np. kościół w Husowie), jak i wykonanie prac stabilizacyjnych o różnej skali (por. pustelnia w Dukli i kościół w Niewodnej). Istotnym z punktu widzenia konserwatorskiego zagadnieniem jest odrębna specyfika reakcji na przemieszczenia osuwiskowe w przypadku oddziaływań na konstrukcje drewniane i murowane. 
Jednym z zagrożonych obiektów murowanych jest gotycki kościół z 1364 r. w Czchowie nad Dunajcem, który znajduje się na granicy rozległego osuwiska (ok. 8 ha) (ryc. 1A, B). Ruchy masowe w tym rejonie rozwijały się zapewne już w odległej przeszłości na łagodnie nachylonym stoku zbudowanym z łupków pstrych, piaskowców i łupków warstw godulskich oraz lgockich (Skoczylas-Ciszewska, 1954). W wyniku uruchomienia się osuwiska, w okresie między majem a lipcem 2010 r. powstały znaczące uszkodzenia w zabudowie znajdującej się w granicach osuwiska oraz w kamiennym ogrodzeniu wokół kościoła. Są to szczeliny o szerokości do $4 \mathrm{~cm}$ (ryc. 1B, C). Liczne pęknięcia ścian kościoła są mniejszej szerokości, a ich stan zachowania wskazuje, że pochodzą z wcześniejszych okresów aktywności osuwiska. Obszar osuwiska jest w dużej części zagospodarowany obiektami powstałymi w różnych okresach. Zabytkowy kościół liczy już ponad 600 lat, pozostała zabudowa (budynki mieszkalne, szkoła) na terenie osuwiska pochodzą z ostatniego stulecia. Sukcesywne zabudowywanie niekorzystnie wpływa na stateczność zbocza i bezpieczeństwo znajdujących się tam budowli.

Niezwykle cennym obiektem zabytkowym zagrożonym przez osuwisko jest prawdopodobnie najstarszy zachowany w Polsce dwór szlachecki, który znajduje się w miejscowości Wieruszyce w województwie małopolskim (Rydel, 2018). Jego historia sięga XV w. Od czasu powstania był kilkakrotnie przebudowywany, jednakże do czasów współczesnych zachowała się jedynie część budowli, niemal połowa uległa zniszczeniu. Północna zachowana część kamiennego dworu przylega do granicy aktywnego osuwiska. Według M. Rydla (2018) zburzenia części dworu dokonali w czasie najazdu Szwedzi, nie ma jednak pewności, czy czynnikiem destrukcyjnym nie były także ruchy masowe, których przejawy obserwuje się współcześnie $\mathrm{w}$ miejscu, gdzie znajdowała się nieistniejąca dzisiaj część budowli (ryc. 2). Wzgórze, na którym znajduje się dwór, a także przylegające do niego osuwisko tworzą wąską elewację zbudowaną z piaskowców istebniańskich dolnych (Kopciowski i in., 2017). Stoki wzniesienia erodowane były niegdyś przez wody Stradomki. Obecnie koryto rzeki znajduje się ok. $200 \mathrm{~m}$ od podnóża osuwiska i nawet w czasie wysokich stanów przepływające wody nie podcinają już zbocza, a pomimo tego osuwisko nadal przejawia aktywność. Dolina rzeki przebiega przez rozległą strefę uskokową o przebiegu N-S, co prawdopodobnie determinuje rozwój ruchów masowych w tym rejonie (Laskowicz, 2016). Osuwisko w najwyższej części jest obecnie aktywne i bezpośrednio zagraża zachowanej części dworu (ryc. 2).

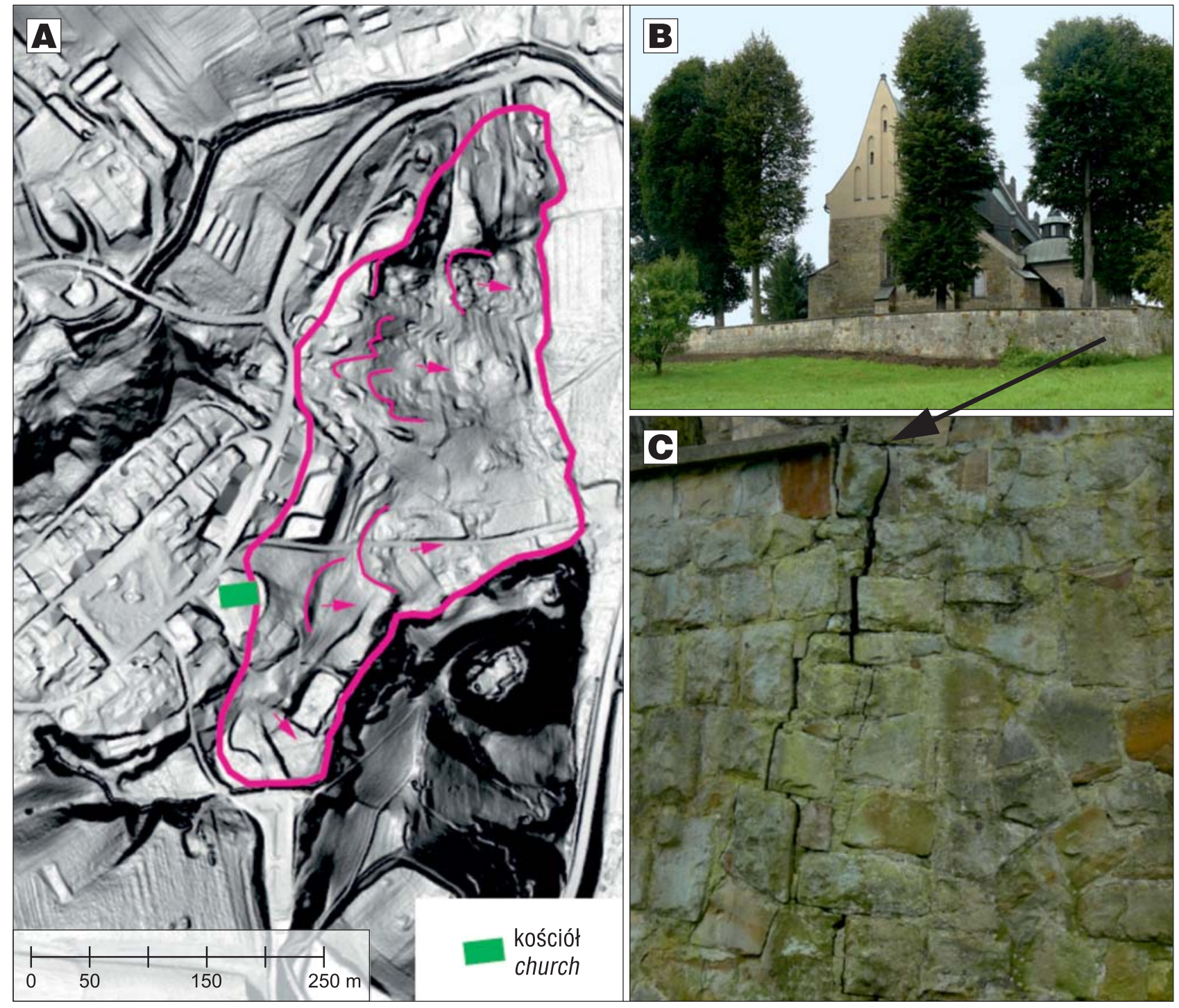

Ryc. 1. Kościół na osuwisku w Czchowie: A-osuwisko, B - widok ogólny zabytkowego kościoła, C - szczeliny w ogrodzeniu Fig. 1. Church on the landslide in Czchów: $\mathbf{A}$ - landslide, $\mathbf{B}$ - general view of the heritage church, $\mathbf{C}-$ cracks in the fence wall 

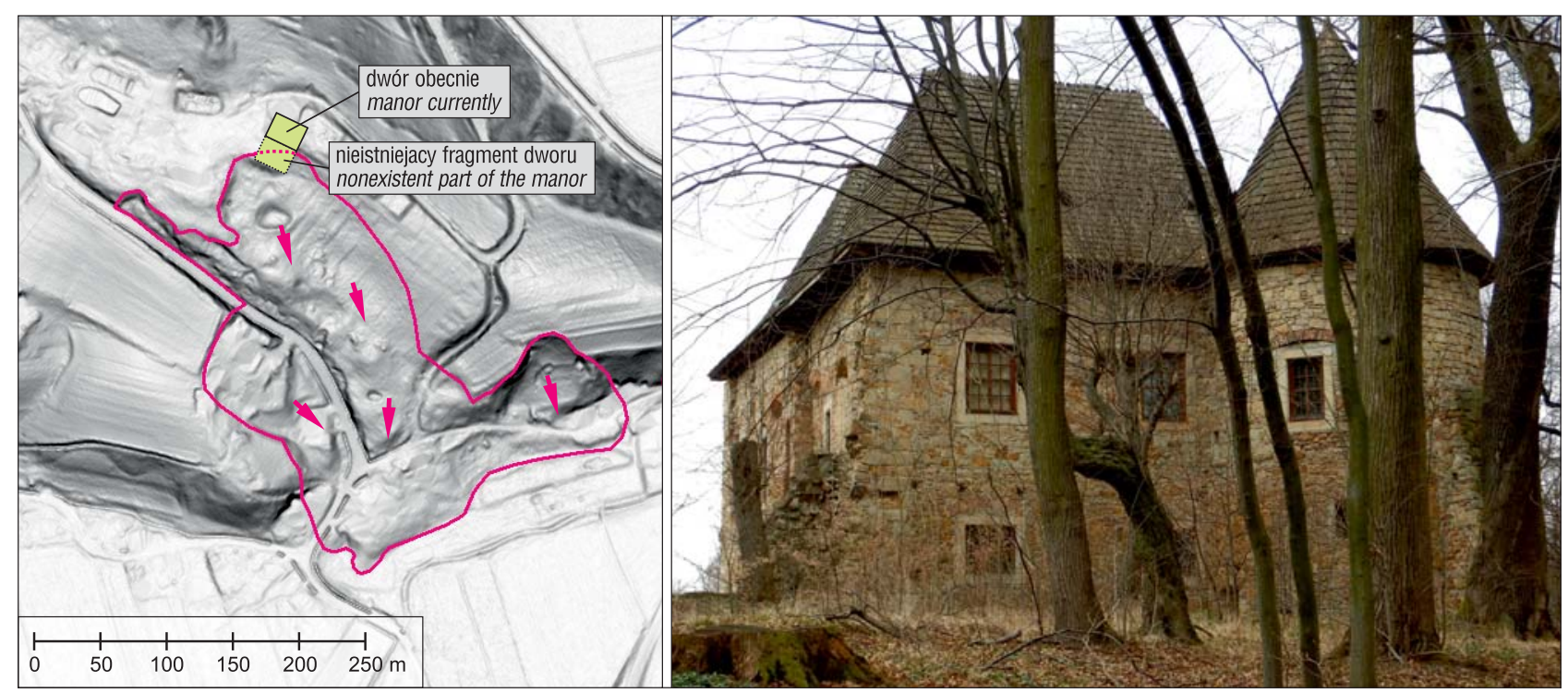

Ryc. 2. Osuwisko i dwór w Wieruszycach

Fig. 2. Landslide and manor in Wieruszyce
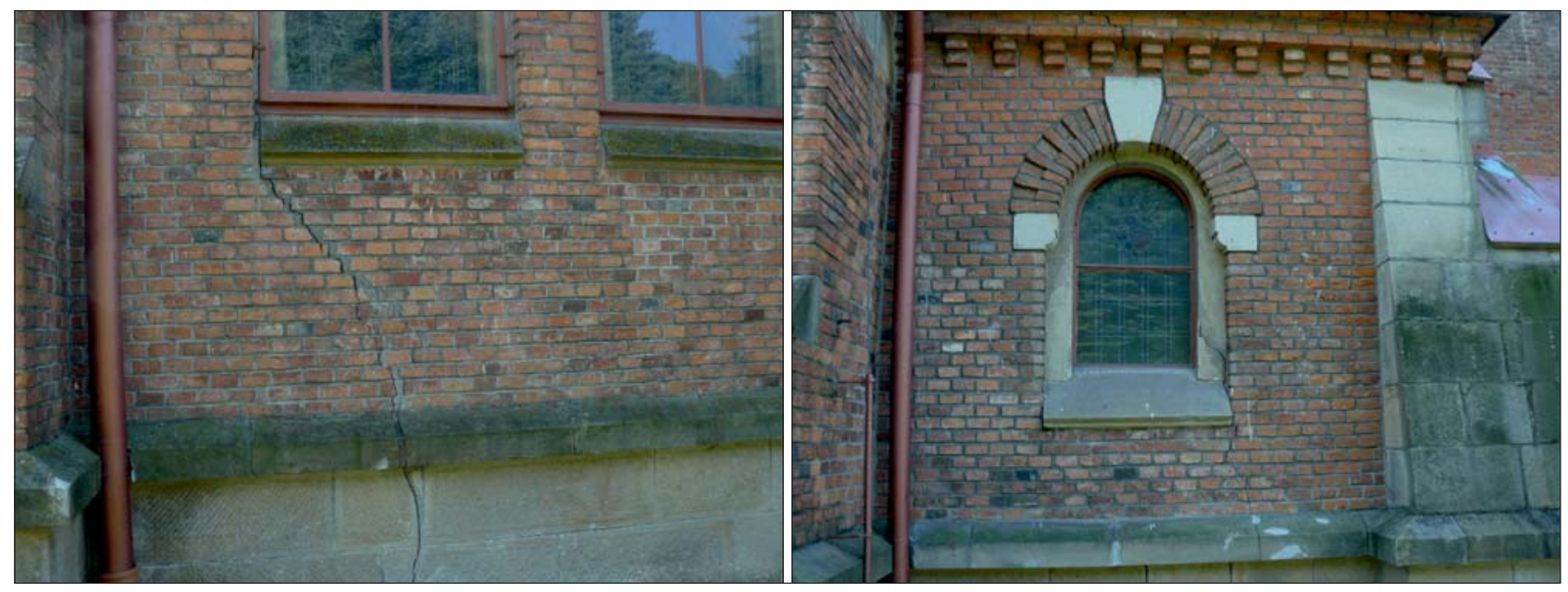

Ryc. 3. Uszkodzenia ścian kościoła w Niewodnej

Fig. 3. Damage of the church walls in Niewodna

Wśród zagrożonych obiektów są też takie, które doczekały się już prac stabilizacyjnych. Należy do nich pochodząca z początku XX w. pustelnia św. Jana z Dukli w Trzcianie szerzej opisana w pracy Laskowicz i Mrozek (2015). Osuwisko, które w 1998 i 2000 r. poważnie naruszyło stabilność zabytkowej budowli, uruchamiało się w przeszłości kilkakrotnie, o czym świadczą wzmocnienia wewnątrz budynku. Po przeprowadzeniu prac stabilizujących najwyższą część osuwiska, gdzie znajduje się pustelnia (Łukasik, Wysokiński, 2001), nie zaobserwowano nowych przejawów uszkodzeń, pomimo wystąpienia ekstremalnie wysokich opadów w $2010 \mathrm{r}$.

Przykładem kompleksowego podejścia do zabezpieczenia osuwiska jest rozwiązanie przyjęte w Niewodnej (województwo podkarpackie). Osuwisko było aktywne kilkakrotnie (ruch odnotowano w 1958, 1980, 2010 r.), powodując coraz większą destrukcję murów neogotyckiego kościoła oraz znajdującej się poniżej drogi powiatowej Różanka-Wiśniowa (ryc. 3). Powiatowy Zarząd Dróg w Strzyżowie w związku z uszkodzeniem drogi przez ruchy masowe zaprojektował stabilizację osuwiska, wraz zabezpieczeniem drogi oraz znajdującego się powyżej

kościoła pw. św. Anny. Wybudowany w latach 20. XX w. kościół nosi liczne ślady dawnych uszkodzeń, o czym świadczą ślady dawnych napraw spękań na ścianach. Widoczne są także nowsze szczeliny o szerokości do $3 \mathrm{~cm}$. W ramach prac stabilizujących podłoża gruntowego wykonano $\mathrm{m}$.in. trzy rzędy pali o długości $12-15 \mathrm{~m}$, tworzących konstrukcje oporowe powyżej (ryc. 4A) i poniżej (ryc. 4B) kościoła, a także odwodnienia wgłębne (Trzpis, Cich, 2013). Pale są zagłębione aż do nienaruszonego masywu zbudowanego z naprzemianległych piaskowców i łupków warstw krośnieńskich górnych o obsekwentnym zaleganiu. Warto podkreślić, w tym przypadku wykonano kompleksowe zabezpieczenie obejmujące stabilizację zarówno osuwiska i zabytkowego kościoła, jak i sąsiadującej z tym terenem drogi powiatowej, na której także odnotowano zniszczenia.

Znacznie bardziej odporne na skutki przemieszczeń wywołanych ruchami masowymi są obiekty zabytkowe o drewnianej konstrukcji. Wynika to zarówno z cech konstrukcji budowlanych dostosowujących się do większego zakresu przemieszczeń podłoża, jak i wytrzymałości na rozciaganie drewna, którego są praktycznie pozbawione obiekty murowane. W Wieliczce na rozległym (22 ha) 


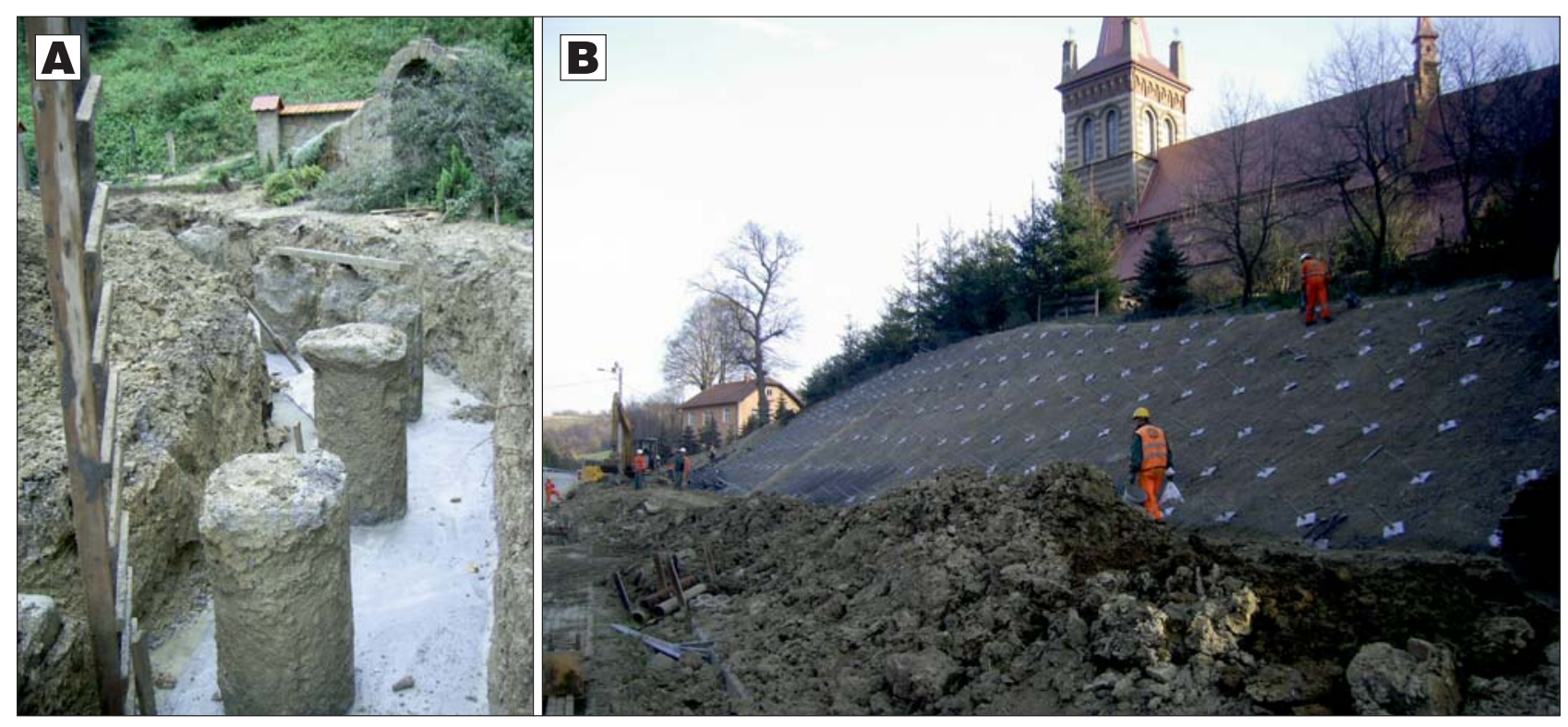

Ryc. 4. Stabilizacja osuwiska z zabezpieczeniem kościoła w Niewodnej: A - pale na stoku powyżej kościoła (foto A. Wójcik), B - pale na stoku poniżej kościoła. Fot. A. Hojdak

Fig. 4. Landslide stabilization with church protection in Niewodna: A-poles on the slope above the church (photo A. Wójcik), B - poles on the slope below the church. Photo by A. Hojdak
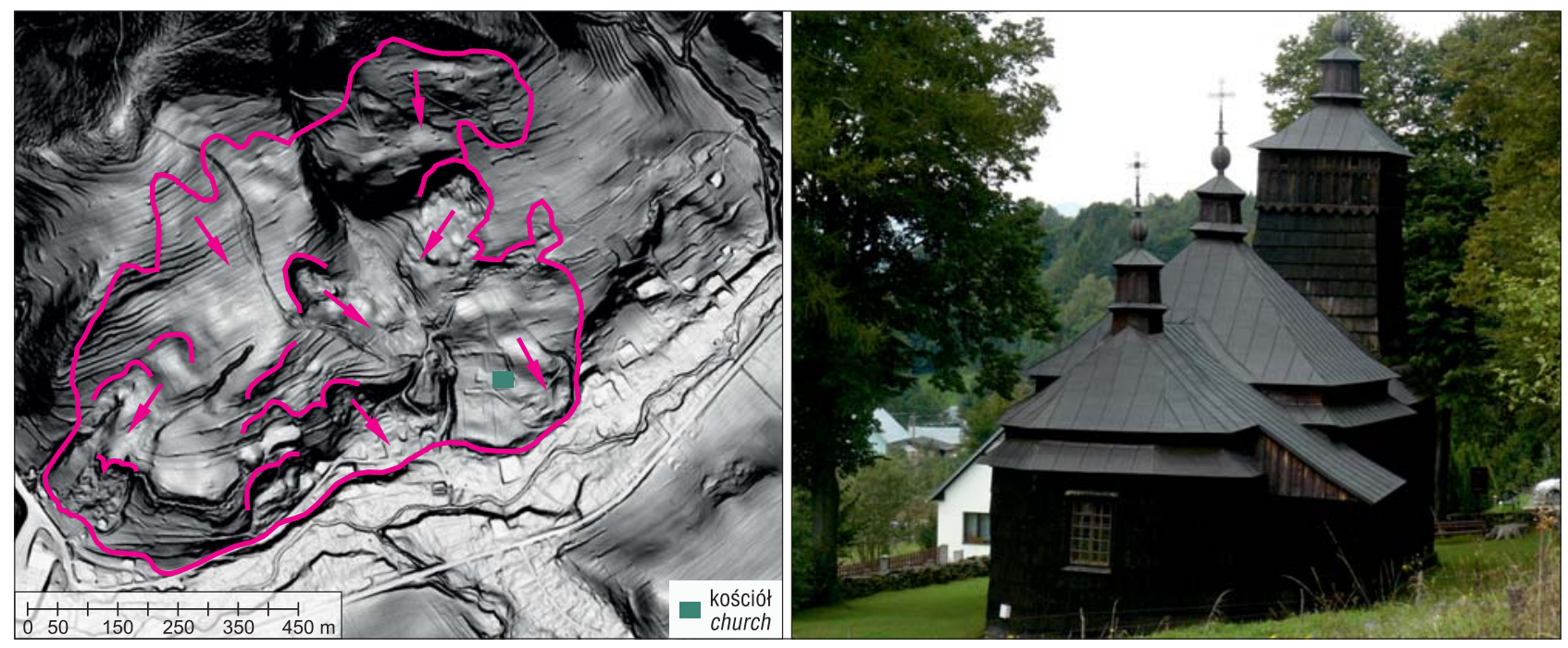

Ryc. 5. Osuwisko i kościół w Leluchowie

Fig. 5. Landslide and church in Leluchów

osuwisku, w znacznej części aktywnym, rozwiniętym na pstrych i szarych marglach węglowieckich znajduje się kościół pw. św. Sebastiana z 1581 r. (Wójcik, 2009). Uszkodzenia są widoczne jedynie na kamiennej posadzce kościoła oraz w obrębie zewnętrznej betonowej opaski wokół budynku, natomiast konstrukcja drewniana kościoła nie nosi znamion uszkodzenia. W celu ochrony przed propagacją przemieszczeń wykonano odwodnienia wokół budynku.

Innym przykładem jest znajdująca się we wsi Leluchów drewniana cerkiew św. Dymitra z 1861 r., która obecnie pełni funkcję kościoła rzymskokatolickiego (ryc. 5). Aktywność osuwiska odnotowano już w 1876 r., a współcześnie ruchy obserwowano w 1997 i 2001 r. Ze względu na powtarzającą się aktywność osuwiska i zagrożenie dla zabytkowego obiektu zostało ono włączone do programu monitorowania $\mathrm{w}$ ramach projektu SOPO (osuwiska.pgi.gov.pl). W granicach osuwiska w trzech otworach zainstalowano inklinometry. Na podstawie pomiarów inklinome- trycznych na różnych głębokościach stwierdzono aktywne powierzchnie poślizgu. Sumaryczne przemieszczenie poziome zarejestrowane po opadach w 2010 r. wyniosło $80 \mathrm{~mm}$ na głębokości $9,5 \mathrm{~m}$ p.p.t. Ruchy masowe na głębokości 22 m p.p.t. były na tyle duże, że rura inklinometryczna została ścięta, co uniemożliwiło prowadzenie dalszych pomiarów (Nescieruk in., 2014). Z kolei przesunięcia strefy przypowierzchniowej są widoczne na pobliskim cmentarzu. Drewniana konstrukcja kościoła w tych warunkach nie wykazuje oznak uszkodzeń.

Ruchy masowe stanowią realne, chociaż zróżnicowane zagrożenie dla obiektów zabytkowych. Tam gdzie uszkodzenia obiektów są obecnie niewielkie z czasem należy się spodziewać ich powiększania, co ostatecznie może doprowadzić do całkowitego zniszczenia, jak w przypadku zabytkowego kościoła w Husowie w województwie podkarpackim. Neogotycka świątynia pod wezwaniem św. Andrzeja Apostoła została wzniesiona w latach 1912-1916. Już na 


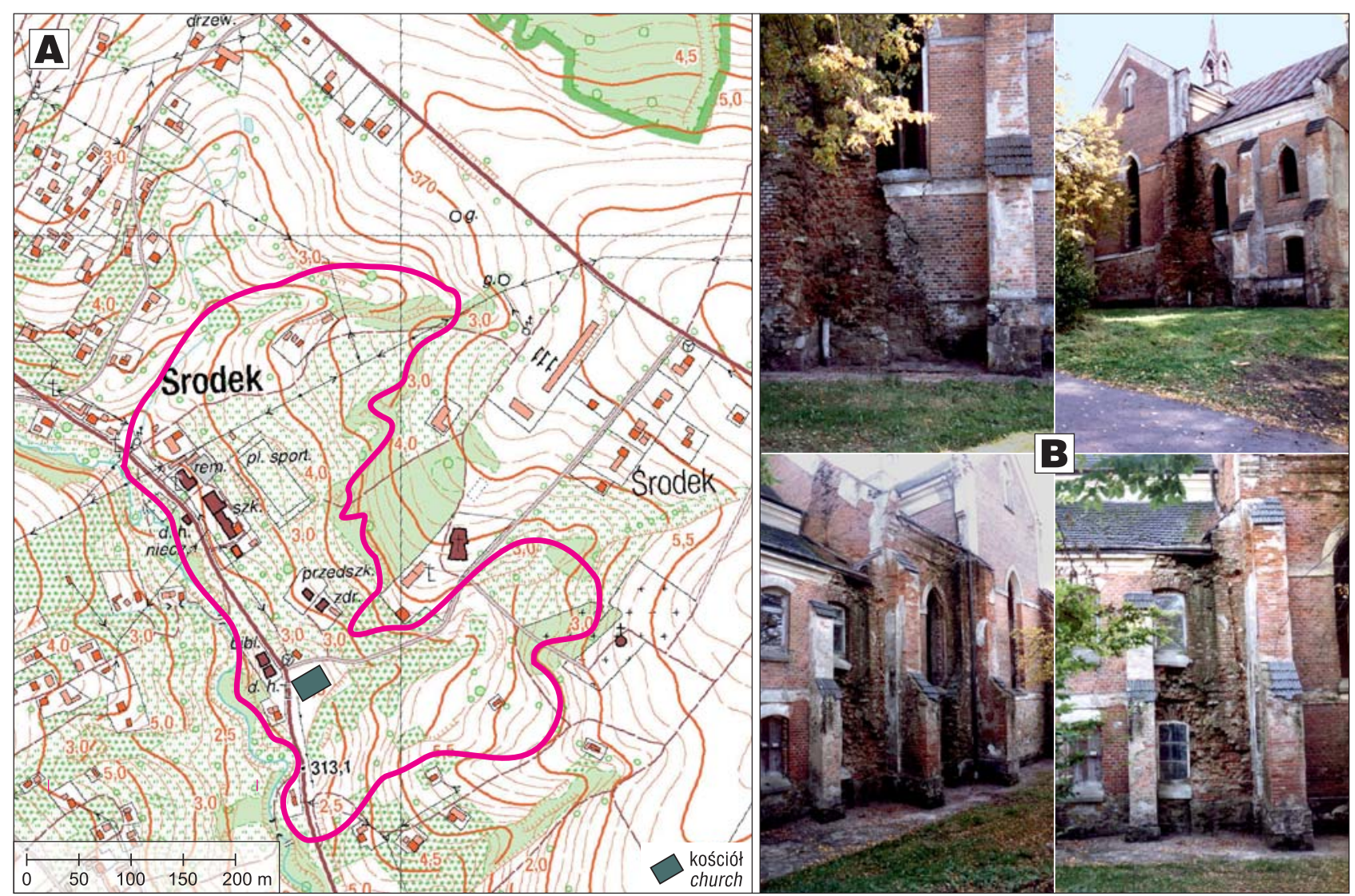

Ryc. 6. Osuwisko i kościół w Husowie: A - mapa osuwiska B - kościół; zdjęcia z 2001 r.

Fig. 6. Landslide and church in Husów: A - map of landslide B - church; photos in 2001

etapie budowy pojawiały się oznaki, że jest ona posadowiona na niestabilnym podłożu. Kościół został źle zlokalizowany, w centralnej części rozległego osuwiska, które od co najmniej 100 lat wykazuje stałą lub okresową aktywność (ryc. 6A). Osuwisko jest rozwinięte na piaskowcach cienko- i średnioławicowych oraz łupkach warstw inoceramowych jednostki skolskiej (Kamiński, Piotrowska, 2003). Utwory te wyróżniają się bardzo wysokim współczynnikiem osuwiskowości powierzchniowej sięgającym lokalnie $18 \%$, co świadczy o ich bardzo wysokiej podatności na rozwój ruchów masowych (Wójcik, Zimnal, 1996).

$\mathrm{Z}$ informacji znajdujących się w parafii w Husowie wynika, że poważne zniszczenia murów odnotowano w 1977 i 1995 r. Chociaż przeprowadzano wielokrotne remonty, kościoła nie udało się uratować i ostatecznie w 2008 r. został rozebrany w związku z bardzo daleko posuniętymi uszkodzeniami konstrukcyjnymi (ryc. 6B).

Upamiętnieniem miejsca rozebranego kościoła jest obecnie park, w stosunkowo bezpieczny sposób zagospodarowujący teren osuwiskowy.

\section{PODSUMOWANIE}

Karpaty są obszarem najbardziej zagrożonym przez ruchy masowe w Polsce (Bober, 1984; Wojciechowski i in., 2015; Wójcik, Wojciechowski, 2016). Dlatego ten typ zagrożeń geodynamicznych jest istotnym czynnikiem oddziaływującym na znajdujące się tam obiekty historycznego dziedzictwa kulturowego. W Karpatach jest to łącznie 445 obiektów o charakterze punktowym i obszarowym uznanych za zabytkowe. Jest to lista niepełna, ponieważ analizę zagrożeń osuwiskowych uwzględniono wg stanu inwentaryzacji na koniec 2018 r., obejmującej 82\% powierzchni Karpat Polskich. Po ukończeniu inwentaryzacji ruchów masowych będzie możliwe kompletne zestawienie zagrożonych obiektów historycznych. W zamierzeniu jest stworzenie mapy obiektów zabytkowych usytuowanych w strefach oddziaływania powierzchniowych ruchów masowych. Oczywiście niezbędna wydaje się późniejsza okresowa aktualizacja i reambulacja materiałów kartograficznych oraz bazy zabytków.

Przytoczone przykłady sugerują, że obiekty wymagają indywidualnego podejścia do każdego przypadku, gdyż ich stan zachowania i odporność na ruchy masowe są różne. Za zabytki nieruchome uznawana są bowiem nie tylko obiekty budowle, ale także ich otoczenie, które odznacza się odmienną wrażliwością na ruchy masowe. Przegląd wybranych przykładów skłania do wniosku, że istnieje przede wszystkim realne zagrożenie osuwiskowe dla zabytków o konstrukcji murowanej (przykład kościoła w Czchowie, Husowie, dworu w Wieruszycach), podczas gdy w odniesieniu do obiektów o konstrukcji drewnianej można się spodziewać ich większej trwałości nawet w przypadkach występowania ograniczonych przemieszczeń podłoża (kościoły w Leluchowie i Wieliczce) (Laskowicz, Mrozek, 2015; Pilecka i in., 2017).

Obecnie prowadzone działania związane $\mathrm{z}$ ochroną zabytków przed zagrożeniem powierzchniowymi ruchami masowymi obejmują inwentaryzację osuwisk wraz z informacją o ich możliwych niekorzystnych oddziaływaniach na obiekty historyczne, zagadnienia stabilizacji i zabezpieczania terenów i obiektów oraz instrumentalny monitoring 
osuwisk. Wydaje się, że czynności te są jednak wyrywkowe i niewystarczające. Dotychczas nie sporządzono szczegółowego zestawienia zabytkowych obiektów w różnym stopniu zagrożonych ruchami masowymi. W przyszłości w porozumieniu z NID powinna powstać lista zabytków, w której zostanie oceniony poziom zagrożenia ruchami masowymi, najpilniejsze potrzeby w zakresie zabezpieczania oraz zakres monitorowania przemieszczeń geodynamicznych. Analiza przestrzennego występowania obiektów zabytkowych i dotychczas zarejestrowanych osuwisk wskazuje, że na obszarze Karpat obiektów zagrożonych jest stosunkowo niewiele. Świadczy to o dobrym, chociaż opartym tylko na jakościowych przesłankach i doświadczeniu wybieraniu miejsc pod budowę nawet w odległej przeszłości historycznej. Obecnie wydaje się, że organizacyjnie i finansowo osiagalne jest prowadzenie cyklicznego przeglądu osuwisk i stanu zabytków w celu podejmowania działań technicznych dla ich zachowania jako istotnego składnika dziedzictwa kulturowego.

Autorki składają podziękowania Recenzentom za cenne uwagi i sugestie, szczególnie w zakresie stosowanej terminologii oraz klasyfikacji obiektów zabytkowych.

\section{LITERATURA}

BOBER L. 1984 - Rejony osuwiskowe w polskich Karpatach fliszowych i ich związek z budową geologiczną regionu. Biul. Inst. Geol., 340: $115-158$

BUKAL G. 2013 - Ochrona i zagrożenie wartości zabytków - czyli o skutkach braku wartościowania i co dalej... [W:] Szmygina B. (red.), Wartościowanie zabytków architektury. Polski Komitet Narodowy ICOMOS Muzeum Pałac w Wilanowie: 61-70.

CANUTI P., MARGOTTINI C., FANTI R., BROMHEAD E.N. 2009 Cultural Heritage and Landslides: Research for Risk Prevention and Conservation. [W:] Sassa K., Canuti P. (red.), Landslides Disaster Risk Reduction. Springer: 401-433.

CHOWANIEC J., WÓJCIK A. (red.) 2012 - Osuwiska w województwie małopolskim. Atlas-Przewodnik. Wydaw. Kartogr. Compas.

GERLACH T. 1966 - Współczesny rozwój stoków w dorzeczu dolnego Grajcarka. Pr. Geograf., 52

GIACOMELLI P. 2003 - The economic evaluation of landslide's risk. [W:] Discussion paper for IV ALARM meeting, 26-27 September 2003. Santander.

GRABOWSKI D., MARCINIEC P., MROZEK T., NESCIERUK P. RACZKOWSKI W., WOJCIK A., ZIMNA Z. 2008 - Instrukcja opracowania Mapy osuwisk i terenów zagrożonych ruchami masowymi w skali $1: 10000$. Państw. Inst. Geol. Warszawa.

GRABOWSKI D., PRZYBYCIN A. 2010 - Działania resortu środowiska w zakresie system osłony przeciwosuwiskowej w Polsce. Prz. Geol., 58: 941-945.

GRANICZNY M., KAMIŃSKI M., PIATTKOWSKA A., SURAŁA M. 2012 - Wykorzystanie lotniczego skaningu laserowego do inwentaryzacji i monitoringu osuwiska w rejonie Łaśnicy (gmina Lanckorona), Pogórze Wielickie, Karpaty zewnetrzne. Prz. Geol., 60 (2): 89-94.

KAMIŃSKI M., PIOTROWSKA K. 2003 - Szczegółowa Mapa Geologiczna Polski, ark. Kańczuga. Państw. Inst. Geol., Warszawa.
KOPCIOWSKI R., JUGOWIEC M., LASKOWICZ I. 2017 - Szczegółowa Mapa Geologiczna Polski w skali $1: 50$ 000, ark. Bochnia. Państw. Inst. Geol., Warszawa.

LASKOWICZ I. 2016 - Analiza statystyczna rozmieszczenia osuwisk i nieciagłości tektonicznych w rejonie Bochni. 3 Polski Kongres Geologiczny. Mat. konf., 204-207.

LASKOWICZ I., MROZEK T. 2018 - Redukcja ryzyka osuwiskowego w Polsce - działania ad hoc czy strategia? Pr., Stud. Geograf., 63 (3): 53-66.

LASKOWICZ I., MROZEK T. 2015 - Sacred Historical Heritage Affected by Landslides in the Polish Flysch Carpathians. [W:] Lollino G. i in. (red.), Enginiering Geology for society and Territory, Vol. 8. Springer International Publishing Switzerland: 415-419.

ŁUKASIK S., WYSOKIŃSKI L. 2001 - Osuwisko przy kościele św. Jana z Dukli. [W:] Kaszyńska M. (red.), Awarie budowlane. XX Konferencja Naukowo-Techniczna, Szczecin-Międzyzdroje, 22-26 maja 2001, $2: 511-518$

MUNICH RE: Topics Geo, 2006 - Annual Review: Natural catastrophes 2005, Munich Reinsurance Company, Munich, Germany.

NESCIERUK P., WOJCIECHOWSKI T., KOWALSKI Z., RĄCZKOWSKI W., WARMUZ B., MICHALSKI A. 2014 - Dokumentacja geologiczna $\mathrm{z}$ prac monitoringowych wykonanych na osuwisku $\mathrm{w} \mathrm{m}$. Leluchów. Nar. Arch. Geol. PIG-PIB, Warszawa.

osuwiska.pgi.gov.pl (dostep 09.01.2019).

PILECKA E., WINIARSKA K., MOSKAL M. 2017 - Analiza wpływu rodzaju konstrukcji budynku na terenie osuwiskowym na zagrożenie drogi ruchem osuwiskowym. Bezpieczeństwo i Ekologia, 12: 381-386.

POPRAWA D., RĄCZKOWSKI W., DZIEPAK P., KOPCIOWSKI R., MROZEK T.,NESCIERUK P., ZIMNAL Z. 1998 - Geologiczne skutki powodzi w 1997 roku na przykładzie osuwisk województwa nowosąeckiego. [W:] Starkel L., Grela J. (red.), Powódź w dorzeczu górnej Wisły w lipcu 1997 r. Wydaw. Oddz. PAN, Kraków: 119-132.

RACZKOWSKI W. 2007 - Landslide hazard in the Polisch Flysch Carpathians. Stud. Geom. Carph-Balc., 41: 61-75

RYDEL M. 2018 - Dwór. Polska tożsamość. Zysk i S-ka.

SKOCZYLAS-CISZEWSKA K. 1954 - Szczegółowa Mapa Geologiczna Polski w skali 1 : 50 000, ark. Brzesko. Państw. Inst. Geol., Warszawa. TRZPIS B., CICH L. 2013 - Dokumentacja projektowo-budowlana branża konstrukcyjna. Opracowanie dokumentacji projektowo-budowlanej dla zadania pn. „Likwidacja i zabezpieczenie osuwiska - droga powiatowa nr 1920R Różanka-Wiśniowa w km 3+900 - 4+300”. ATEiRI „mkm PERFEKT” Sp. z o.o. Kraków.

USTAWA z dnia 23 lipca 2003 r. o ochronie zabytków i opiece nad zabytkami. Dz.U. z 2018 r. poz. 2067.

WIRTZ A. 2008 - Hitting the poor: Impact of natural catastrophes in economies at various stages of development, paper presented at International Disaster and Risk Conference (IDRC) 2008 Davos, Davos, Switzerland, 25-29 Aug. JAMES B. ELSNER, Department of Geograph.

WÓJCIK A. 2009 - Szczegółowa Mapa Geologiczna Polski w skali $1: 50$ 000, ark. Wieliczka. Państw. Inst. Geol., Warszawa.

WOJCIECHOWSKI T., MROZEK T., LASKOWICZ I., KUŁAK M. 2015 - Podatność osuwiskowa Polski. I Ogólnopolska Konferencja O! suwisko 19-22 maja 2015, Wieliczka. Mat. konf. PIG-PIB, Warszawa: 119-120.

WÓJCIK A, WOJCIECHOWSKI T. 2016 - Osuwiska jako jeden z ważniejszych elementów zagrożenia geologicznego w Polsce. Prz. Geol., 64 (9): 701-709.

WÓJCIK A., ZIMNAL Z. 1996 - Osuwiska wzdłuż doliny Sanu między Bachórzcem a Reczpolem (Karpaty, pogórze karpackie) Biul. Państw. Inst. Geol., 374: 77-91.

www.nid.pl (dostęp 12.05.2018).

ZIETARA T. 1969 - W sprawie klasyfikacji osuwisk w Karpatach fliszowych. Stud. Geomorph. Carpath.-Balcan., 3: 21-29.

ZÁRUBA Q., MENCL V. 1982 - Landslides and their control. Elsevier Scientific Publishing Company. 